\title{
ANALISIS POLA SEBARAN SEDIMEN UNTUK MENDUKUNG PEMELIHARAAN KEDALAMAN PERAIRAN PELABUHAN MENGGUNAKAN PEMODELAN HIDRODINAMIKA 3D (STUDI KASUS: PELABUHAN TANJUNG PERAK, SURABAYA)
}

\author{
Danar Guruh Pratomo ${ }^{1}$, Krisma Hutanti ${ }^{2}$, Khomsin ${ }^{3}$ \\ 1,2,3 Departemen Teknik Geomatika FTSLK-ITS, Kampus ITS Sukolilo, Surabaya, 60111 \\ e-mail: ${ }^{1}$ guruh@geodesy.its.ac.id, ${ }^{2}$ krisma1412@gmail.com, ${ }^{3}$ khomsin@geodesy.its.ac.id ${ }^{3}$
}

\begin{abstract}
Abstrak
Pelabuhan Tanjung Perak Surabaya merupakan salah satu pelabuhan di Indonesia yang menjadi pusat distributor barang ke kawasan timur Indonesia. Keberadaan sedimen di dalam perairan akan mempengaruhi kondisi fisik perairan pelabuhan tersebut dikarenakan pengendapan sedimen di suatu perairan akan mempengaruhi bentuk topografi di dasar perairan. Pengerukan secara rutin diperlukan untuk memelihara kedalaman suatu kolam dan alur pelayaran dari pendangkalan akibat pergerakan dan pengendapan material sedimen. Salah satu penyebab dari proses sedimentasi adalah arus dan pasang surut air laut. Pasang surut adalah fluktuasi muka air laut karena adanya gaya tarik bendabenda di langit, terutama matahari dan bulan terhadap massa air laut di bumi. Dalam hal ini dilakukan analisis pola sebaran sedimen menggunakan pemodelan hidrodinamika 3D menggunakan perangkat lunak Delft3D. Pemodelan arus dan sebaran sedimen dilakukan menggunakan metode simulasi numerik dengan parameter data batimetri, pasang surut air laut, river discharge, densitas, dry density dan konsentrasi sedimen. Dari penelitian ini didapatkan hasil nilai sebaran sedimen paling besar terjadi pada saat spring tide mencapai $2 \times 10-3 \mathrm{~m} 2 / \mathrm{s}$. Berdasarkan data kumulatif erosi dan sedimentasi, daerah perairan Pelabuhan Tanjung Perak yang mengalami sedimentasi paling besar adalah kolam pelabuhan, Terminal Teluk Lamong dan daerah sekitar bangunan jetti, sehingga diperlukan monitoring secara rutin di daerah tersebut.
\end{abstract}

Kata Kunci: Arus, Delft3D, Pasang Surut, Pemodelan, Pelabuhan, Sedimentasi

\begin{abstract}
Tanjung Perak Port in Surabaya is one of the ports in Indonesia which is the center of goods distributor to the eastern region of Indonesia. The presence of sediments in the waters will affect the physical condition of the waters of the port due to sediment deposition in a waters will affect the topography in the bottom of the waters. Routine dredging is required to maintain the depth of a port basin and the access channel from silting due to the movement and deposition of sediment materials. Two of the causes of the sedimentation process are the currents and tides. Tides are sea level fluctuations due to the attraction of objects in the sky, especially the sun and moon to the mass of sea water on earth. In this case, the pattern of sediment distribution analyzed using 3D hydrodynamic modeling using Delft3D software. Modeling of current and sediment distribution are performed using numerical simulation method with parameters of bathymetry data, sea tides, river discharge, density, dry density and sediment concentration. From this research, the highest value of sediment distribution occurs when spring tide and reaches $2 \times 10^{-3} \mathrm{~m}^{2} / \mathrm{s}$. Based on the cumulative data of erosion and sedimentation, the waters of Tanjung Perak Port with the largest sedimentation are the port basin, Lamong Bay Terminal and the area around the Jetti building. Consequently, in these location should be monitored frequently.
\end{abstract}

Keywords: Current, Delft3D, Modeling, Port, Sedimentation, Tides 


\section{PENDAHULUAN}

Pelabuhan laut di Jawa Timur memegang peranan yang sangat strategis dalam kegiatan perekonomian Jawa Timur dan Nasional. Tanjung Perak merupakan salah satu pintu gerbang Indonesia, yang berfungsi sebagai kolektor dan distributor barang dari dan ke Kawasan Timur Indonesia, termasuk Jawa Timur. Karena letaknya yang strategis dan didukung oleh dataran gigir atau hinterland yang potensial maka Tanjung Perak juga merupakan Pusat Pelayaran Interinsuler Kawasan Timur Indonesia.

Keberadaan sedimen di dalam perairan akan mempengaruhi kondisi fisik perairan tersebut, hal ini karena pengendapan sedimen di suatu perairan akan mempengaruhi bentuk topografi di dasar perairan tersebut. Transpor sedimen merupakan perpindahan material sedimen dari suatu tempat tertentu ke tempat lainnya. Perpindahan ini berupa penambahan (inflow) atau pengurangan material (outflow). Proses sedimentasi atau pengendapan di suatu perairan dapat menimbulkan permasalahan jika terjadi di perairan pelabuhan karena dapat menyebabkan adanya pendangkalan perairan. Salah satu penyebab dari proses sedimentasi ini adalah arus dan pasang surut air laut. Pasang surut adalah fluktuasi muka air laut karena adanya gaya tarik benda-benda di langit, terutaman matahari dan bulan terhadap massa air laut di bumi (Triatmodjo, 1999) sedangkan arus adalah pergerakan suatu massa air dari suatu tempat ke tempat yang lain yang disebabkan oleh tiupan angin atau disebabkan oleh pergerakan pasang surut air laut (Hafli, 2014).

Model matematik (hidrodinamika) adalah simulasi numerik suatu aliran air yang didasarkan pada formulasi persamaan-persamaan matematik yang menggambarkan prinsip hidraulika, atau yang menggambarkan fenomena fisik aliran, dan penyelesaian persamaan-persamaan tersebut secara numeris. Persamaan aliran yang digunakan Delft3D adalah persamaan Navier Stokes untuk incompressible fluid pada perairan dangkal. Pada persamaan momentum arah vertikal, percepatan vertikal ditiadakan, yang mengarah ke persamaan tekanan hidrostatik (Novico, Astjario dan Bachtir, 2013).

Penelitian ini dilakukan dengan tujuan untuk mengetahui area perairan Pelabuhan Tanjung Perak yang mengalami pendangkalan dan membutuhkan pengerukan. Area yang membutuhkan pengerukan dapat diketahui dari perubahan morfologi karena erosi dan sedimentasi. Sebelum itu harus dilakukan pemodelan arus pasang surut sebagai pembangkit dari pergerakan sedimen. Pemodelan arus pasang surut di perairan Pelabuhan Tanjung Perak didapatkan dari pembangkit arus yaitu dengan memasukkan data pasang surut dan river discharge. Dari pemodelan tersebut juga dapat diketahui pola arus dan pasang surut yang dapat digunakan untuk melihat arah pergerakan sedimen. Setelah pola dari arus pasang surut diketahui, selanjutnya dapat dilakukan analisis untuk pola sebaran sedimen yang diakibatkan oleh pergerakan arus.

\section{METODE}

\section{Lokasi Penelitian}

Lokasi penelitian berlokasi di Pelabuhan Tanjung Perak, Surabaya, Jawa Timur yang terletak pada posisi geografis $7^{\circ} 09^{\prime} 50^{\prime \prime}$ LS - $7^{\circ} 13^{\prime} 30^{\prime \prime}$ LS dan $112^{\circ} 39^{\prime} 03^{\prime \prime}$ BT - $112^{\circ} 44^{\prime} 53^{\prime \prime}$ BT dengan batas wilayah, yaitu:

- Sebelah Utara: Selat Madura dan Pulau Madura

- Sebelah Timur: Selat Madura dan Surabaya

- Sebelah Selatan: Surabaya

- Sebelah Barat: Gresik

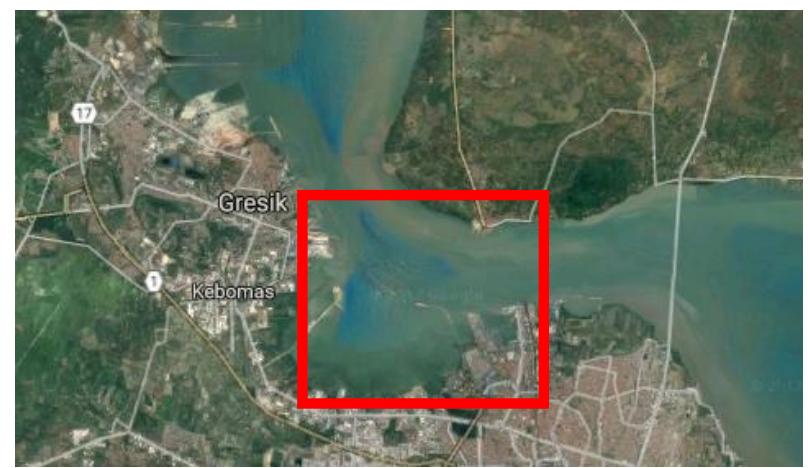

Gambar 1. Lokasi Penelitian (Google Maps, 2017)

\section{Data dan Peralatan}

Data yang digunakan dalam penelitian ini merupakan data primer dan data sekunder dengan rincian sebagai berikut: Peta Laut Pelabuhan Surabaya dan Gresik dengan skala 1:12500 tahun 2016, Peta RBI wilayah Surabaya dengan skala 1:25000 tahun 1999, Data batimetri perairan Pelabuhan Tanjung Perak, Data pasang surut perairan Pelabuhan Tanjung Perak bulan Desember tahun 2017, Data river discharge Sungai 
Kalimas dan sungai-sungai yang bermuara ke Teluk Lamong yaitu Sungai Kalianak, Sungai Greges, Sungai Lamong, Sungai Sememi, Sungai Branjangan dan Sungai Manukan dan sampel sedimen perairan Pelabuhan Tanjung Perak.

Adapun peralatan yang digunakan dalam penelitan ini adalah berupa perangkat lunak pengolah data, antara lain: ArcGIS 10.3 yang digunakan untuk mendigitasi garis pantai dan titik kedalaman, Delft3D digunakan untuk melakukan pemodelan hidrodinamika, Matlab R2014a digunakan untuk pengolahan data pasang surut dan Perangkat lunak untuk mengkonversi format data.

\section{Pengolahan Data}

Adapun tahapan pengolahan data sebagai berikut:

1. Melakukan pembuatan doamin model dengan merekftifikasi Peta RBI dan mendigitasi garis pantai untuk mendapatkan garis pantai dengan ketinggian $0 \mathrm{~m}$ dari MSL. Hasil digitasi digunakan untuk boundary model simulasi. Pembuatan grid dilakukan dengan menggunakan RGFGRID pada perangkat lunak Delft3D. Ukuran grid disesuaikan dengan kebutuhan detail area yang diperlukan.

2. Setelah domain dibuat selanjutnya melakukan digitasi menggunakan ArcGIS pada titik kedalaman di peta laut untuk mendapatkan nilai kedalaman perairan Pelabuhan Tanjung Perak. Selanjutnya melakukan konversi data kedalaman menjadi format file ascii untuk dijadikan data sampel kedalaman. Lalu membuat interpolasi data kedalaman dengan metode Triangulasi Interpolation.

3. Tahap setelahnya adalah melakukan input parameter pemodelan. Input parameter pemodelan dilakukan di Delft3D $\rightarrow$ Flow $\rightarrow$ Flow Input. Setelah itu memasukkan parameter pada pilihan Domain, Time Frame, Processes, Initial Condition, Boundary, Physical Parameters, Numerical Parameters dan Monitoring. Parameter untuk memodelkan arus dan sedimen yang dimasukkan adalah data batimetri, elevasi pasang surut, river discharge, konsentrasi, densitas dan dry density sedimen.

4. Setelah pemodelan berhasil dibuat, maka seterusnya dilakukan validasi data hasi pemodelan. Validasi data pasang surut hasil simulasi model dengan data pasang surut pengamatan di lapangan dilakukan untuk mengetahui keakuratan secara matematis data hasil pemodelan. Validasi data didapat dengan menggunakan MAE (Mean Absolute Error) dan RMSE (Root Mean Square Error). Perhitungan untuk mencari nilai tersebut adalah:

$$
\begin{aligned}
& M A E=\frac{1}{n} \sum_{i=1}^{n}\left|y_{i}-\hat{y}_{i}\right| \\
& R M S E=\sqrt{\frac{\sum_{i=1}^{n}\left(y_{i}-\hat{y}_{i}\right)^{2}}{n}}
\end{aligned}
$$

Dengan $n, y_{i}$, dan $\hat{y}_{i}$ berturut-turut adalah jumlah data, data lapangan dan data hasil pemodelan.

\section{HASIL DAN PEMBAHASAN}

\section{Bidang Model}

Pembuatan bidang pemodelan ini dilakukan dengan menggunakan batas pemodelan dan data kedalaman hasil pengukuran batimetri. Batas pemodelan dibuat berdasarkan data garis pantai daerah Teluk Lamong dan Pulau Madura yang berada di wilayah Pelabuhan Tanjung Perak dan garis lurus untuk batas perairan.

Setelah pendefinisian batas, langkah selanjutnya dalam pembuatan bidang model ini adalah pembuatan grid. Pembuatan grid ini dilakukan menggunakan rectangular grid.

Hasil proses pembuatan grid dengan Delft3D ditampilkan pada Gambar 2 sebagai berikut:

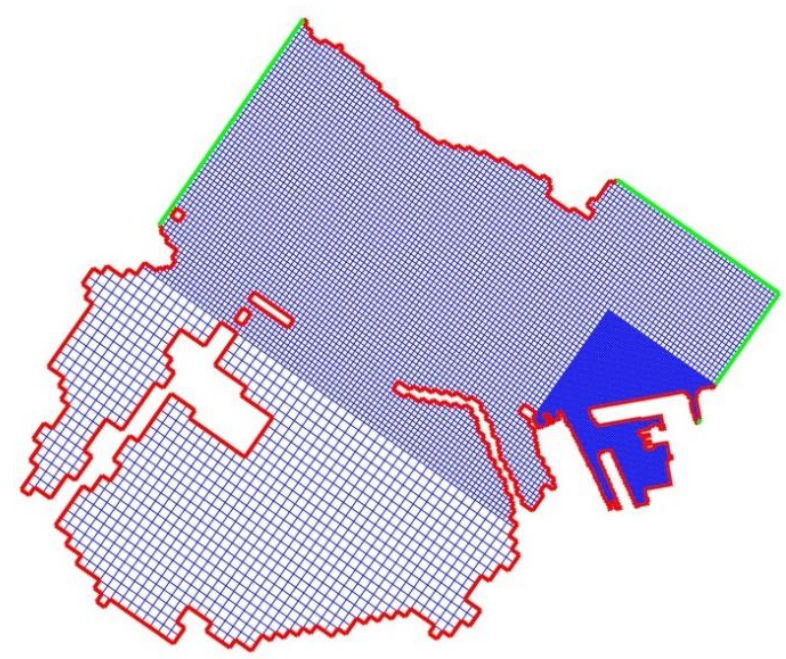

Gambar 2. Grid Pemodelan

Pada area Pelabuhan Tanjung Perak menggunakan grid dengan ukuran $20 \times 20 \mathrm{~m}$ di kolam pelabuhan, $60 \times 60 \mathrm{~m}$ di Alur Pelayaran Barat 
Surabaya dan 120x120m di Teluk Lamong. Dalam perairan Pelabuhan Tanjung Perak, terdapat 2 sisi garis pantai, yaitu pada sisi Pulau Jawa dan Pulau Madura. Untuk close boundary ditandai dengan garis tebal berwarna merah. Juga terdapat garis lurus berwarna hijau pada perairan sebagai tanda batas untuk open boundary yang yang bertindak sebagai batas air virtual.

Sistem proyeksi UTM yang digunakan adalah 49S. Satuan atau unit yang digunakan untuk menyatakan baik koordinat horizontal $(x, y)$ maupun kedalaman ( $z$ ) adalah meter (m). Referensi kedalaman yang digunakan dalam pembuatan model ini adalah MSL (Mean Sea Level) atau duduk muka air laut rata-rata.

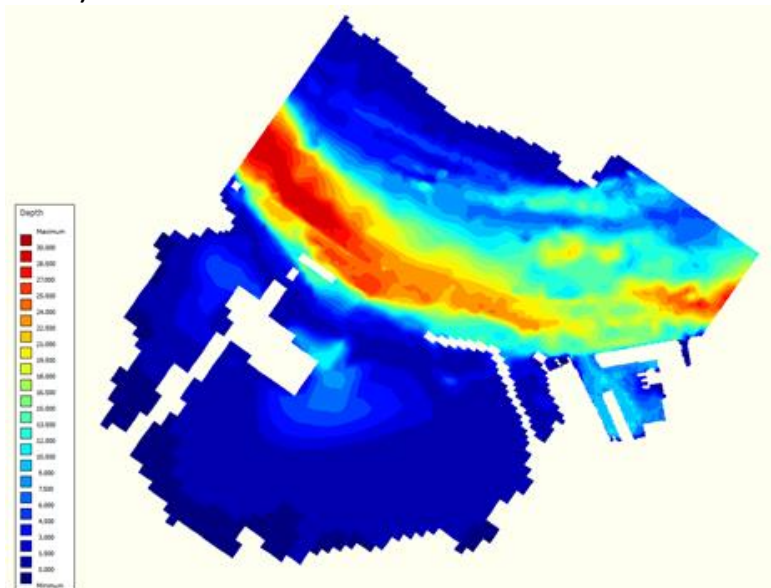

Gambar 3. Hasil Interpolasi Kedalaman

Gambar 3 merupakan interpolasi dari titiktitik kedalaman yang dilakukan terhadap tiap grid menggunakan metode Triangular Interpolation dalam Delft3D.

Dari data kedalaman yang telah diperoleh dapat diketahui bahwa data kedalaman perairan Pelabuhan Tanjung Perak paling dalam sebesar 29,33 m dan kedalaman terdangkal sebesar 0,1 m dengan kedalaman rata-rata $17,89 \mathrm{~m}$.

Waktu yang digunakan untuk proses simulasi arus dan sebaran sedimen adalah berikut:
a. Tanggal Mulai
: 26 November 2017
b. Tanggal Berakhir
: 26 Desember 2017
c. Lama Simulasi
: 30 hari
d. Interval
: 15 menit
e. Spin Up Time
: 720 menit
f. Warming Up Time
$: 4,5$ hari
g. Time Step
: 0.01 menit

\section{Pemodelan Arus}

Pemodelan arus dilakukan dengan menggunakan metode simulasi numerik dengan berdasarkan pada persamaan kontinuitas dan kekekalan momentum. Arus yang dimodelkan menggunakan pembangkit pasang surut dan debit sungai (river discharge).

Komponen sungai dimasukkan sebagai variabel untuk melihat sebaran debit air dari muara sungai ke perairan Pelabuhan Tanjung Perak Surabaya. Pada penelitian ini data debit sungai yang digunakan berasal dari 7 sungai yang bermuara ke perairan Pelabuhan Tanjung Perak dan Teluk Lamong, yaitu menggunakan data Sungai Lamong, Sungai Sememi, Sungai Branjangan, Sungai Manukan, Sungai Greges, Sungai Kalianak dan Sungai Kalimas.

\begin{tabular}{clc}
\begin{tabular}{c} 
Tabel 1. Data Debit Sungai di Perairan Tanjung Perak \\
\cline { 1 - 2 } No
\end{tabular} & Nama Sungai & $\begin{array}{c}\text { Debit Sungai Rata-Rata } \\
\left(\mathrm{m}^{3} / \mathrm{s}\right)\end{array}$ \\
\hline $\mathbf{1}$ & Sungai Lamong & 19 \\
$\mathbf{2}$ & Sungai Sememi & 4,3 \\
$\mathbf{3}$ & Sungai Branjangan & 3,6 \\
$\mathbf{4}$ & Sungai Manukan & 5,8 \\
$\mathbf{5}$ & Sungai Greges & 3,5 \\
$\mathbf{6}$ & Sungai Kalianak & 3,5 \\
$\mathbf{7}$ & Sungai Kalimas & 10,35 \\
\hline
\end{tabular}

Data pengamatan pasang surut dari stasiun di perairan Surabaya didapat dari Sea Level Station Monitoring Facility mulai tanggal 26 November 2017 sampai dengan tanggal 26 Desember 2017.

Pasang surut di perairan Pelabuhan Tanjung Perak memiliki nilai MSL 1,879 m; HWL 2,980 m; LWL 0,779 m dan 1,413 untuk nilai Formzahl. Nilai Formzahl tersebut menunjukkan pasang surut di daerah Pelabuhan Tanjung Perak memiliki tipe mixed tides prevailing semi diurnal atau campuran condong harian ganda sehingga dalam satu hari bisa terjadi dua kali pasang dan dua kali surut dengan ketinggian dan interval yang berbeda.

Untuk pemodelan arus dibutuhkan pasang surut yang telah direferensikan pada MSL atau duduk muka air rata-rata. Salah satu hasil yang didapatkan dari pemodelan adalah perubahan muka air atau pasang surut. Pasang surut hasil pemodelan ini menunjukkan kenaikan muka air pada model di waktu tertentu. Karena arus yang dimodelkan dibangkitkan dengan dominasi pasang surut, maka data pasang surut hasil pemodelan ini dapat digunakan untuk melakukan validasi hasil model.

Berikut adalah grafik perbandingan pasang surut pengamatan dengan hasil pasang 
surut pemodelan menggunakan perangkat lunak Delft3D yang sudah beracuan terhadap MSL.

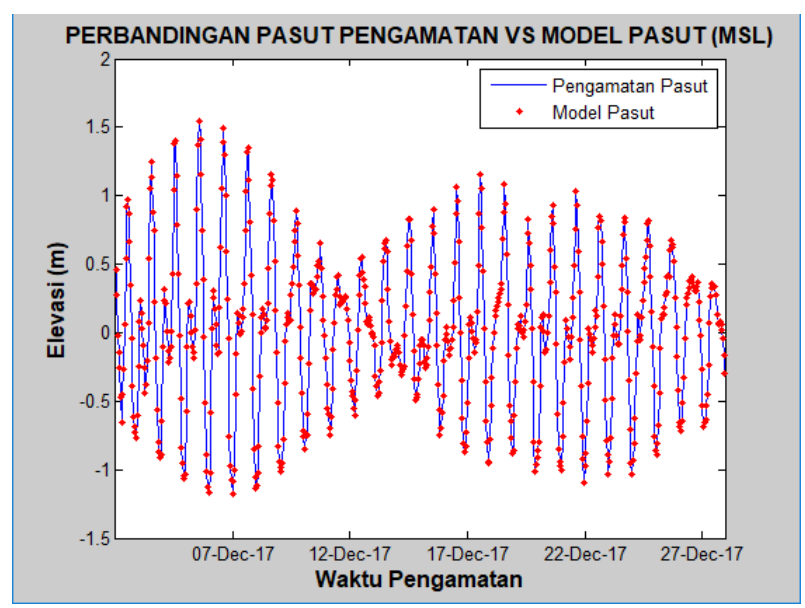

Gambar 4. Grafik Perbandingan Pasang Surut

Dari data pasang surut pengamatan dan pasang surut hasil model, dapat dilakukan validasi hasil pemodelan. variasi kesalahan yang terjadi pada sampel Validasi dilakukan dengan perhitungan Root Mean Square Error (RMSE) dan Mean Absolute Error (MAE). Bersama-sama, nilai RMSE dan MAE menunjukkan data tersebut. Semakin besar beda antara RMSE dan MAE, maka semakin besar pula variasi/perbedaan masigmasing kesalahan sampel yang dihitung (Khotimah 2012). Mean Absolute Error merupakan salah satu cara dalam model evaluasi untuk membandingkan data model dan data observasi. MAE cocok untuk menggambarkan kesalahan yang terdistribusi secara merata (Chai dan Draxler 2014). Mean Absolute Error diperoleh dengan menjumlahkan nilai absolut dari kesalahan untuk mendapatkan kesalahan total dan kemudian membaginya dengan $n$ (Willmott dan Matsuura 2005). Dalam perhitungan untuk menguji validitas pemodelan, nilai observasi yang digunakan adalah nilai pasang surut pengamatan. Sedangkan nilai model menggunakan data pasang surut hasil pemodelan. Dengan nilai $\mathrm{n}$ adalah 623 dari banyaknya data pasang surut setelah melewati waktu warming up yang berarti dimulai dari tanggal 1 Desember 2017.

Dari perhitungan validasi data didapatkan bahwa nilai Mean Absolute Error dan Root Mean Square Error adalah 0,001 m dan 0,003 m yang mendekati nilai 0 . Berdasarkan nilai MAE dan RMSE di atas, tingkat kesalahan pada data pasang surut pemodelan ini masuk ke dalam kategori kecil, sehingga dapat ditarik kesimpulan bahwa algoritma pemodelan berjalan baik dan data dapat diterima sehingga bisa dilanjutkan ke dalam tahap selanjutnya.

Analisa pemodelan arus dilakukan pada saat terjadi pasang surut purnama atau spring tide dan pasang surut perbani atau neap tide. Spring tide terjadi pada tanggal 4 dan 5 Desember 2017 pada pukul 13:59 WIB dan 23:59 WIB untuk masing-masing pasang dan surut. Sementara neap tide terjadi pada tanggal 12 Desember 2017 pada pukul 18:59 WIB untuk surut dan pukul 23:59 WIB untuk pasang. Analisa terhadap hasil pemodelan arus pasang surut dalam masing-masing kondisi adalah sebagai berikut.



Gambar 5. Pola Arus Kondisi Pasang Purnama

Model pola arus saat kondisi pasang purnama pada Gambar 5 terjadi pada tanggal 4 Desember 2017 pukul 13:59 WIB dengan time step 825. Kecepatan arus saat pasang purnama paling tinggi sekitar $1,3 \mathrm{~m} / \mathrm{s}$ di daerah dekat Pelabuhan Gresik dengan tanda lingkaran merah. Arus kencang bergerak dari arah Pelabuhan Gresik karena merupakan open boundary dengan pasang surut sebagai pembangkit dan masuk ke arah Teluk Lamong, kolam pelabuhan dan ke arah timur Selat Madura.

Model pola arus saat surut purnama pada Gambar 6 terjadi pada time step 961 tanggal 5 Desember 2017 pukul 23:59 WIB. Arus berasal dari sungai di sekitar Teluk Lamong dan Sungai Kalimas menuju ke Alur Pelayaran Barat Surabaya ke arah timur. Arus juga keluar dari arah kolam pelabuhan. Arus kencang berada di daerah sungai yang dibangkitkan dari river discharge dengan kecepatan berkisar $1 \mathrm{~m} / \mathrm{s}$.

Model pola arus saat pasang perbani pada Gambar 7 terjadi pada time step 1633 tanggal 12 
Desember 2017 pukul 23:59 WIB. Arus berasal dari arah Pelabuhan Gresik menuju ke Teluk Lamong, Alur Pelayaran Barat Surabaya dan kolam pelabuhan menuju terus ke arah timur. Arus berkecepatan tinggi dengan kecepatan berkisar 1 $\mathrm{m} / \mathrm{s}$ berada di sekitar open boundary yang membangkitkan arus menggunakan river discharge dan pasang surut air laut.



Gambar 6. Pola Arus Saat Kondisi Surut Purnama



Gambar 7. Pola Arus Saat Kondisi Pasang Perbani

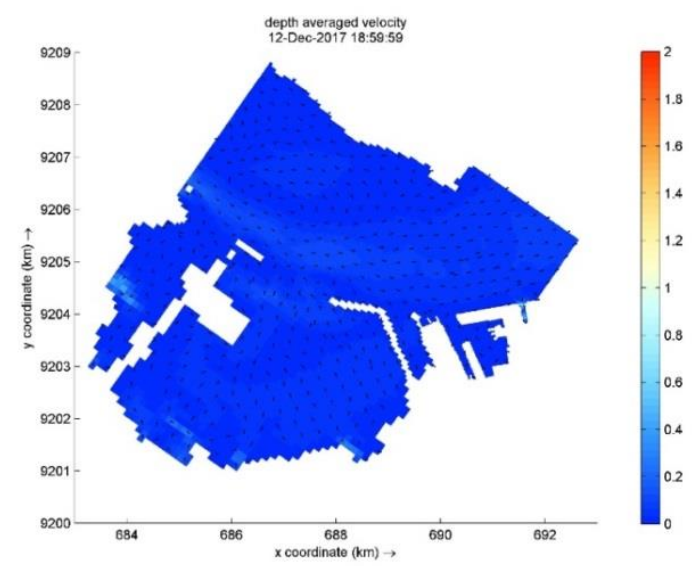

Gambar 8. Pola Arus Saat Kondisi Surut Perbani
Model pola arus saat surut perbani pada Gambar 8 terjadi pada time step 1613 tanggal 12 Desember 2017 pukul 18:59 WIB. Arus keluar dari sungai di sepanjang Teluk Lamong, Sungai Kalimas dan dari arah Pelabuhan Gresik menuju Alur Pelayaran Barat Surabaya dan bergerak ke arah timur. Arus kencang terlihat tetap berada di sekitar open boundary yang membangkitkan arus dengan river discharge dan pasang surut air laut dengan kecepatan arus paling kecil sebesar 0 $\mathrm{m}^{2} / \mathrm{s}$.

\section{Pemodelan Sebaran Sedimen}

Pemodelan sebaran sedimen menggunakan parameter arus yang dibangkitkan oleh pasang surut dan debit sungai. Jenis sedimen yang dimodelkan adalah sedimen kohesif yang berupa butiran - butiran partikel lumpur. Data sampel sedimen diambil dari Sungai Kalimas dengan nilai densitas $1188 \mathrm{~kg} / \mathrm{m} 3$, dry density $884 \mathrm{~kg} / \mathrm{m} 3$ dan konsentrasi sedimen sebesar $0.0129 \mathrm{~kg} / \mathrm{m} 3$.

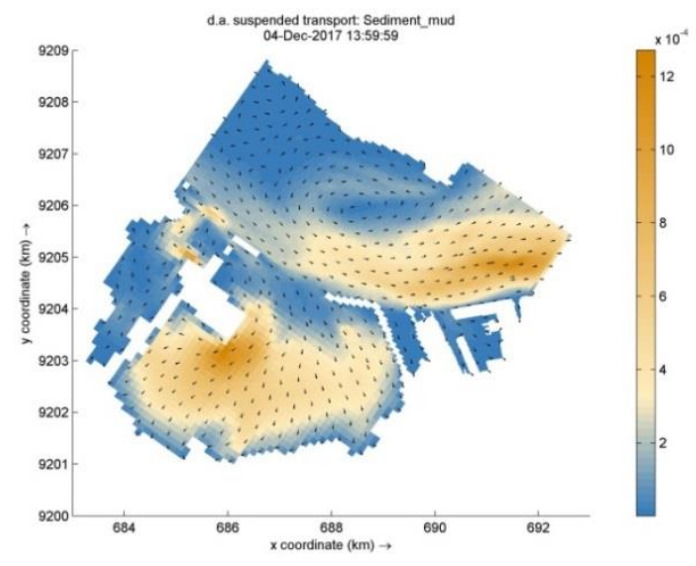

Gambar 9. Sebaran Sedimen Saat Pasang Purnama

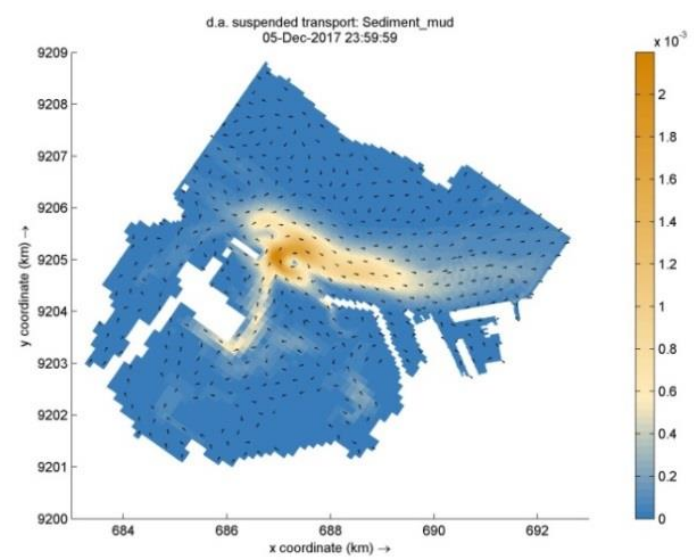

Gambar 10. Sebaran Sedimen Saat Surut Purnama 
Analisa pemodelan sebaran sedimen dilakukan dalam empat kondisi, yaitu pada saat spring tide dan neap tide pada tanggal 12 Desember 2017.

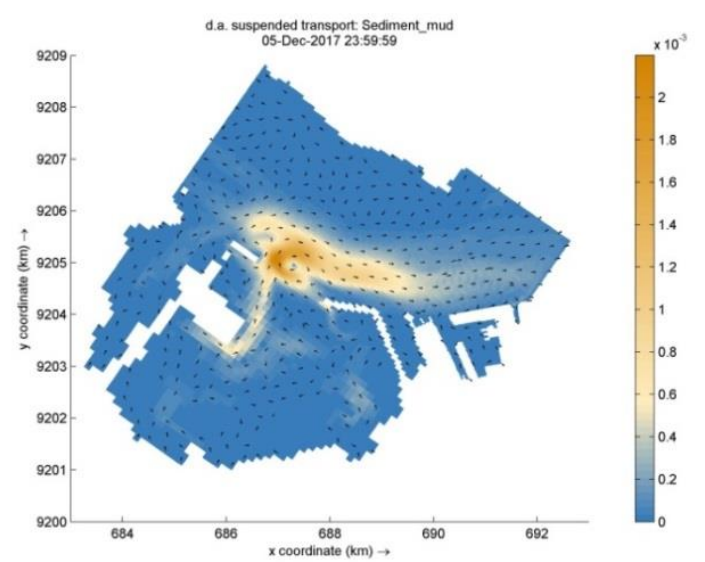

Gambar 11. Sebaran Sedimen Saat Pasang Perbani

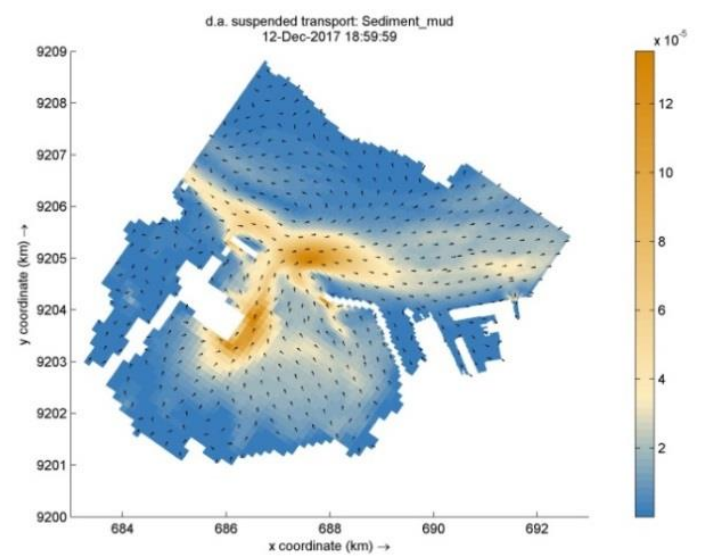

Gambar 12. Sebaran Sedimen Saat Surut Perbani

Nilai sebaran sedimen paling besar terjadi pada saat spring tide terjadi. Besar total transport sedimen mencapai lebih dari $2 \times 10^{-3} \mathrm{~m}^{2} / \mathrm{s}$. Setelah dilakukan perhitungan rata-rata besar nilai depth averaged suspended transport di perairan Pelabuhan Tanjung Perak pada tanggal 4 Desember 2017 adalah sebesar 25,632 m²/hari. Pada saat pasang surut perbani besar total transport sedimen hanya mencapai $12 \times 10^{-5} \mathrm{~m}^{2} / \mathrm{s}$ pada pasang maupun surut dan rata-rata 7,776 $\mathrm{m}^{2} / \mathrm{s}$. Faktor penyebabnya adalah kecepatan arus pada saat spring tide yang relatif lebih cepat dibandingkan pada saat neap tide. Hal ini menunjukkan semakin cepat arus, maka sedimen yang terbawa dapat semakin banyak sesuai dengan teori yang dikemukakan oleh Triatmodjo (1999).
Penentuan area yang membutuhkan pengerukan pada perairan pelabuhan dilakukan dengan melihat perubahan morfologi yang terjadi akibat transport sedimen, erosi dan sedimentasi. Data perubahan morfologi yang diakibatkan oleh perpindahan material sedimen dapat dilihat pada gambar 13 sampai dengan gambar 15 berikut:

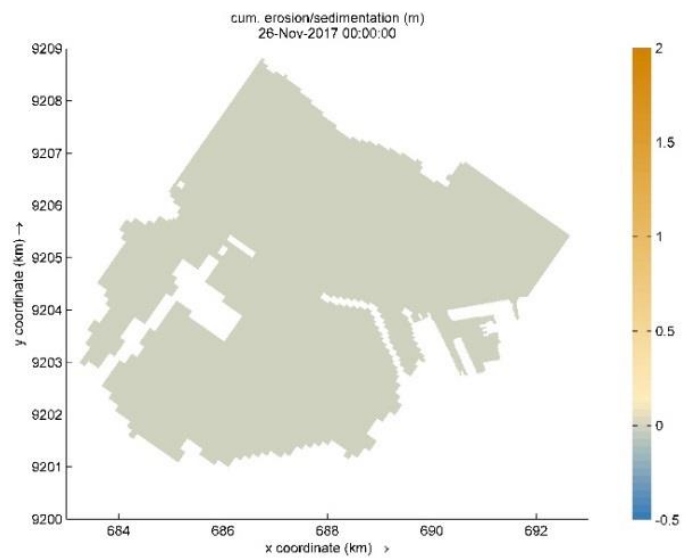

Gambar 13. Kumulatif Erosi dan Sedimentasi tanggal 26 November 2017

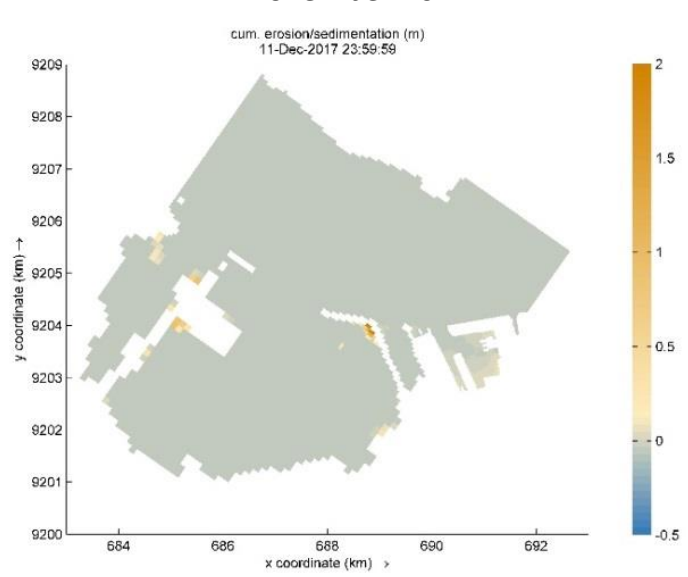

Gambar 14. Kumulatif Erosi dan Sedimentasi tanggal 11 Desember 2017

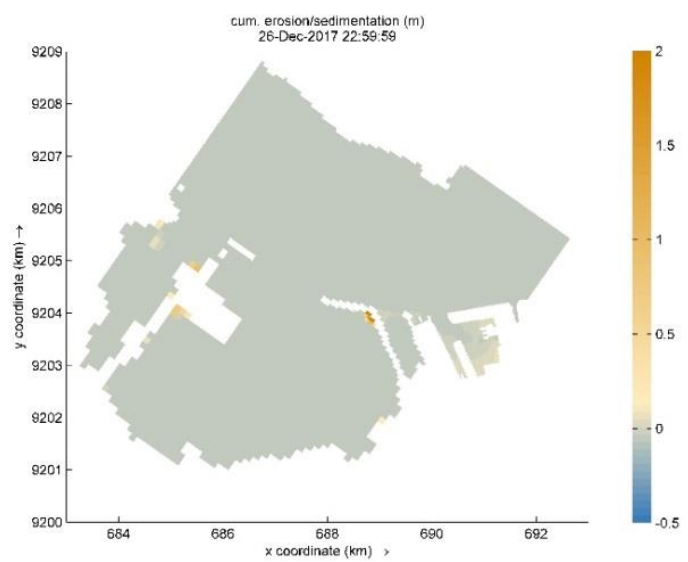

Gambar 15. Kumulatif Erosi dan Sedimentasi tanggal 26 Desember 2017 
Berdasarkan Gambar 13 - 15, daerah perairan Pelabuhan Tanjung Perak yang mengalami sedimentasi paling besar adalah Terminal Teluk Lamong, jetti dan kolam pelabuhan. Hal ini dikarenakan sedimen yang terbawa masuk oleh arus ke dalam kolam pelabuhan tidak sebanding dengan sedimen yang terbawa ke luar. Pada bangunan jetti dan Terminal Teluk Lamong pergerakan sedimen terlahang sehingga sebagian besar mengendap. Sedangkan pada daerah Arus Pelayaran Barat Surabaya perubahan morfologi relatif kecil karena partikel sedimen mengendap dan terbawa oleh arus secara terus menerus.

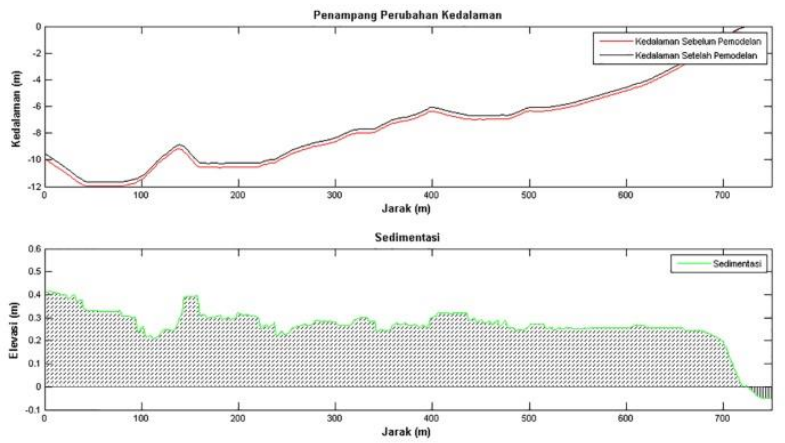

Gambar 16. Penampang Perubahan Kedalaman Sebelum dan Setelah Pemodelan

Perubahan kedalaman dapat terlihat lebih jelas dengan gambar dari profil di atas. Gambar 16 memperlihatkan penampang kedalaman di kolam pelabuhan. Terlihat pada gambar di atas bahwa telah terjadi perubahan kedalaman sebelum dan setelah dilakukan pemodelan. Kedalaman perairan mengalami perubahan menjadi lebih dangkal, hal itu membuktikan bahwa setelah dilakukan simulasi selama 1 bulan di lokasi tersebut telah terjadi pengendapan sedimen atau sedimentasi.

Lokasi Kolam Pelabuhan terletak pada grid berukuran $20 \times 20 \mathrm{~m}$ dan seluruh area seluas 226,223 ha mengalami sedimentasi sebesar $8020,629 \mathrm{~m}^{3}$. Sementara bangunan jetti terletak pada grid $60 \times 60 \mathrm{~m}$ dengan luas keseluruhan area sebesar 2121,455 ha dan sedimentasi yang terjadi adalah sebesar $54285,67 \mathrm{~m}^{3}$. Pada area Terminal Teluk Lamong dengan grid berukuran $120 \times 120 \mathrm{~m}$ yang melingkupi area seluas 1524,990 ha mengalami sedimentasi sebesar 61299,48 $\mathrm{m}^{3}$. Ketiga area memiliki lebar grid yang berbeda-beda dan menyebabkan hal tersebut berpengaruh pada detail hasil yang didapatkan. Semakin kecil ukuran grid maka semakin detail hasil yang diperoleh.
Oleh karena itu untuk menjaga kedalaman perairan Pelabuhan Tanjung Perak perlu dilakukan monitoring kedalaman secara rutin pada wilayah tersebut agar dapat diketahui apabila kedalaman sudah tidak lagi sesuai dengan draft kapal. Jika daerah yang dimaksud sudah mengalami sedimentasi berlebih hingga tidak sesuai dengan ukuran draft kapal maka perlu diberi tindakan penanggulangan berupa pengerukan pada daerah perairan oleh PT. Pelindo III selaku pengelola Pelabuhan Tanjung Perak.

\section{KESIMPULAN}

Kesimpulan yang didapatkan dari penelitian pemodelan pola arus dan sebaran sedimen di perairan Pelabuhan tanjung Perak ini adalah:

1. Pasang surut di daerah Pelabuhan Tanjung Perak memiliki tipe campuran condong harian ganda. Kecepatan arus paling tinggi di saat spring tide yaitu $1,3 \mathrm{~m} / \mathrm{s}$ dan paling rendah saat neap tide sebesar $0 \mathrm{~m} / \mathrm{s}$.

2. Nilai sebaran sedimen pada kedalaman ratarata paling besar terjadi pada spring tide. Besar depth averaged suspended transport sedimen saat spring tide mencapai lebih dari $2 \times 10^{-3} \mathrm{~m}^{2} / \mathrm{s}$ dan rata-rata $25,632 \mathrm{~m}^{2} /$ hari. Pada saat neap tide besar depth averaged suspended transport sedimen hanya mencapai $12 \times 10^{-5} \mathrm{~m} 2 / \mathrm{s}$ dan $7,776 \mathrm{~m}^{2} / \mathrm{s}$.

3. Berdasarkan Pada daerah perairan Pelabuhan Tanjung Perak yang mengalami sedimentasi paling besar adalah kolam pelabuhan, Terminal Teluk Lamong dan daerah sekitar bangunan jetti, sehingga diperlukan monitoring secara rutin di daerah tersebut.

\section{UCAPAN TERIMA KASIH}

Penulis mengucapkan terima kasih kepada PT. Pelabuhan Indonesia III, Perum Jasa Tirta dan PT. Terminal Teluk Lamong yang telah banyak memberi bantuan berupa data dalam penelitian ini sehingga dapat berjalan dengan lancar.

\section{DAFTAR PUSTAKA}

Hafli, T. 2014. Simulasi Numerik Perubahan Morfologi Pantai Akibat Konstruksi Jetty Pada Muara Lambada Lhok Aceh Besar Menggunakan Software Delft3D, Aceh: Universitas Syiah Kuala. 
Khotimah, Mia Khusnul. 2012. Validasi Tinggi Gelombang Sigifikan Model Gelombang WindWave-5 dengan Menggunakan Hasil Pengamatan Satelit Altimetri Multimisi, Thesis, Depok: Universitas Indonesia.

Novico, Franto. Astjario, Prijantono. Bachtir, Huda. 2013. Kondisi Arus Pasang Surut dan ErosiSedimentasi di Sekitar Garis Pantai Depan PLTU Tarahan Lampung Menggunakan Delft3D versi 3.28. Jurnal Geologi Kelautan.

T. Chai, R.R. Draxler. 2014. Root mean square error (RMSE) or mean absolute error (MAE)? Arguments against avoiding RMSE in the literature. Geoscientific Model Development, 7, 1247-1250.

Triatmodjo, Bambang. 1999. Teknik Pantai. Yogyakarta: Beta Offset.

Willmott, C., Matsuura, K., 2005. Advantages of the Mean Absolute Error (MAE) over the Root Mean Square Error (RMSE) in Assessing Average Model Performance, Climate Research, 30, 79-82. 